\title{
Designing a Web-Based Thesis Title Submission System Using the Codeigniter 3 Framework
}

\author{
M. Herman ${ }^{1, *}$ \\ ${ }_{1}^{1}$ Informatics and Computer Engineering Education IAIN Bukittinggi, Bukittinggi, Indonesia
}

\begin{tabular}{l} 
Article Information \\
\hline Article History: \\
Accepted by Editor: May 06, 2021 \\
Final Revision: June 15, 2021 \\
Published Online: 30 June 2021 \\
Keywords \\
\hline Essay \\
Codeigniter \\
Web \\
R\&D \\
$4 \mathrm{D}$ \\
Correspondence
\end{tabular}

E-mail: hermancareall@gmail.com*

\begin{abstract}
A B S T R A C T
Thesis is a scientific work made by every student on the basis of conducting a research to complete a bachelor's degree program (S1) guided by the guidance of a lecturer who has the capability of the field of study/final project. There are still many students who are confused during the title submission process. There is no information system provided for the submission of Thesis Title, and There is no information system provided by the Information Technology and Computer Education Study Program to submit the thesis title to the Study Program. The type of research used is Research and Development (Research and Development). In this study, researchers used a system model taken from the life cycle, namely the System Development Life Cycle (SDLC). SDLC is one of the traditional ways to maintain, build and replace an information system. From the product test that the author did, the results obtained were the Validity test was obtained with a number of 0.87 with valid criteria, the Practicality test by the supervisor was obtained a value of 0.91 with very practical criteria and the effectiveness test by students of the Informatics and Computer Engineering Education Study Program obtained a score of 0.89 with criteria Very effective. This study aims to produce a Title Submission system WebBased Thesis which is validated and describes its validity, practicality and effectiveness.
\end{abstract}

\section{Introduction}

A thesis is one of the works of science were created by each student with a foundation to research for, completing studies undergraduate degree program (S1) guided by the guidance of the lecturers who have the capability on the field of study/assignments end them. [1] When carrying out the guidance process to complete the thesis, there is a time frame set according to the academic schedule by the study program concerned. It is a stage that every student wants because they have got many things that should have been done after finishing from the lecture bench, so students spend much time focusing on going through the process which utilizes all the abilities they get in lectures and of course, students also want to show skills that maybe not everyone has them. In some circumstances, students certainly want to get qualified results with the time that has been planned. However, many students still get some obstacles that make the schedule fall apart, causing many of the students to cross the limits set by the study program, citing the many obstacles encountered in the thesis guidance process, which begins with submissions. Title, thus 
causing the student concerned to experience delays in completing his studies and forcing them to extend the time until the next semester to complete their thesis.

In this case, the campus does not yet provide an online-based system for the title submission process, so this has several obstacles in deciding whether the student title has been previously submitted or not and whether or not a title can be accepted. Students do not get answers and clear evidence from the Lecturer and the head of the study program because only the study program has a database of student thesis titles, while students cannot consider the title to be submitted by looking at references from the existing database. It can also negatively impact the study program and students because the thesis is the last and very decisive stage to get a bachelor's degree. [2]

\section{Method}

The type of research used is Research and Development. Research and development is a term that refers to research conducted as part of the process of making a product and testing the effectiveness of the product. R\&D ( Research and Development ) is a research method used to develop and validate educational and learning materials. [3] The researcher used the 4-D version of the Research and Development (Four D) research stage. The explanation behind the selection of researchers from step 4-D. This is because the stages of this research can be applied in the process of making applications that researchers will make, the 4-D (Four D) stages are easy to follow, and the dissemination stage allows researchers to conduct trials and revisions to applications that will be made repeatedly in addition to distribute products.. Research and development steps are abbreviated as 4-D ( Four D), which stands for Define, Design, Develop, Disseminate. [4] (1). Define is the stage in the process of determining and defining the desired needs of a system (2). Design is the process of designing a system in outline, (3). Develop is a technical step taken in making the system, (4). Disseminate is the last step in distributing the product to users.

The system development model uses a system model lifted from the life cycle, namely the System Development Life Cycle (SDLC). The method taken is the waterfall method : (1). Communication is the process of collecting data (2). Planning is the preparation of a work plan (3). Modeling is the translation of the software requirements used (4). Construction is the stage of building software that has been designed. (5). Deployment is the final stage and maintenance will be carried out.

The testing process in this study includes validity testing, practicality testing, and effectiveness testing. While the instrument used in the testing process is a questionnaire.

\subsection{Validity Test}

Uji Validity test To get a high quality product, it is necessary to carry out a test using the following statistical formula Aiken's V [4].

$$
\mathrm{v}=\sum \mathrm{s} /[\mathrm{n}(\mathrm{c}-1)]
$$

With $\mathrm{s}=\mathrm{r}-\mathrm{lo}$, where lo is the smallest number of validity searches and $\mathrm{r}$ is the value of the validator, $\mathrm{C}$ is the highest number of validity searches and $\mathrm{n}$ is the value of the validator [4]. The value of the validity criteria can be seen in Table 1 .

Table 1. Criteria for Determining Validity

\begin{tabular}{cc}
\hline Percent $\%$ & Criteria \\
\hline $0,6<$ & Invalid \\
$>=0,6$ & Valid \\
\hline
\end{tabular}




\subsection{Practical Test}

The aspect that is assessed is the assessment of the user or users in terms of the practical use of the product. The results of the test are guided by the following formula [6].

$$
P=\frac{\left(\sum f\right)}{N} \times 100 \%
$$

Description:

$\mathrm{P}=$ final result

$\mathrm{f}=$ score

$\mathrm{n}=$ highest score

The value of the validity criteria can be seen in Table 2 .

Table 2. Criteria for Determining Practicality

\begin{tabular}{cc}
\hline Score & Description \\
\hline$\leq 0.20$ & Not practical \\
$0.01-0.20$ & Very low \\
$0.21-0.40$ & Low \\
$0.41-0.60$ & Currently \\
$0.61-0.80$ & Tall \\
0.811 .00 & Very high \\
\hline
\end{tabular}

\subsection{Effectiveness Test}

The effectiveness test is the final stage of the product being tested. The effectiveness test is the result of measuring the equivalence of the initial objectives with the program results. The effectiveness test is carried out by referring to the statistical formula of Richard R. Hake ( G-Score ) below [7].

$$
\langle g\rangle=\frac{(\%\langle S f\rangle-\%\langle S i\rangle)}{(100-\%\langle S i\rangle)}
$$

\section{Description:}

$<\mathrm{g}>$ : G-Score

$<$ Sf $>$ : Final Score

$<\mathrm{Si}>$ : Initial Score

The criteria are as follows: (1). " High-g " is high effectiveness if it has $(<\mathrm{g}>)>0.7 ;(2)$. " Medium-g " is moderately effective if it has $0.7>(<\mathrm{g}>)>0.3$; (3). " Low-g " effectiveness is low if it has $(<\mathrm{g}>)<0.3$.

\section{Results and Discussion}

The results of this study are based on the research that the researcher has done and the description can be understood that with the presence of a Thesis Title Submission system design, the researcher has succeeded in making a Web-based thesis title submission system using codeigniter 3 in the PTIK IAIN Bukittinggi Study Program. Generates a website with the URL https://abs.orbitiainbkt.com . The existence of this information system is very helpful for the Study Program, especially the Head of the Study Program and Students in the Administrative Process of Submitting a thesis so that the results will be more valid, practical, and effective.

The system for submitting the title of this thesis uses PHP/MySql as the programming language and Codeigniter as the web platform of the system. This system can submit Thesis Title, Announcement of 
acceptance and rejection of Thesis Title idea, Announcement of Proposal Seminar Schedule, Comprehensive Session, and Munaqasah Session of students of the Informatics and Computer Engineering Education Study Program IAIN Bukittinggi.

This system can also help the Secretary of the Study Program and the Head of Study Program to back up Student Data for Thesis Guidance in One system. The Thesis Title Submission System can act as a forum for managing Guidance Student data and Session Schedule Data. With this system, the study program can improve the quality of study program administration, data recap of student thesis titles and data of supervisors. Besides being useful for Study Programs, this system is also useful for students who want to do Thesis Guidance and most importantly when submitting a Student Thesis Title.

Figure 1 is the system access flow by admin.

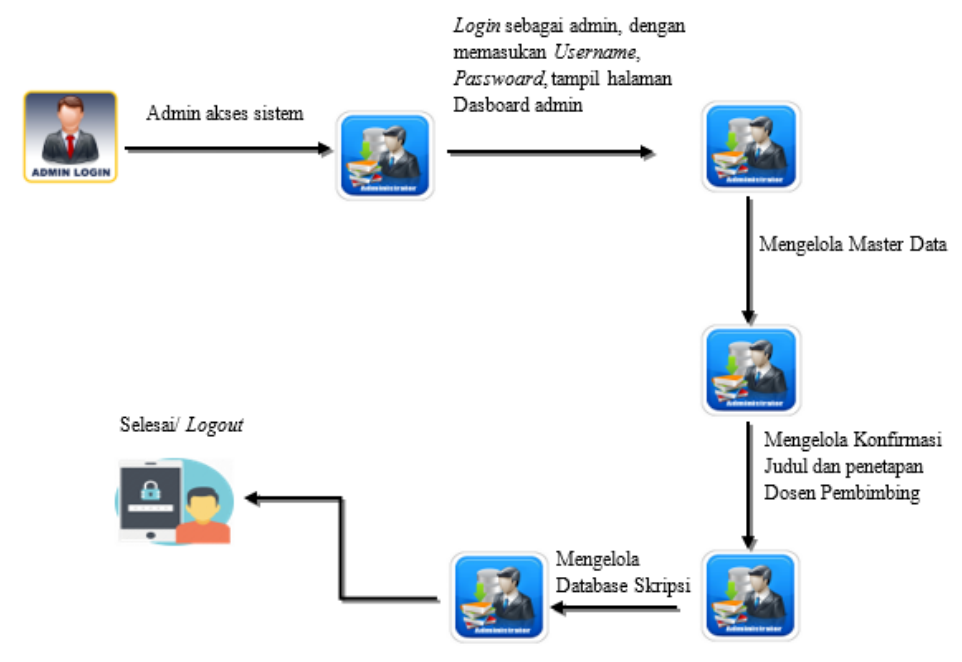

Figure 1. System Access Flow by Admin

Figure 2 is the system access flow for students.

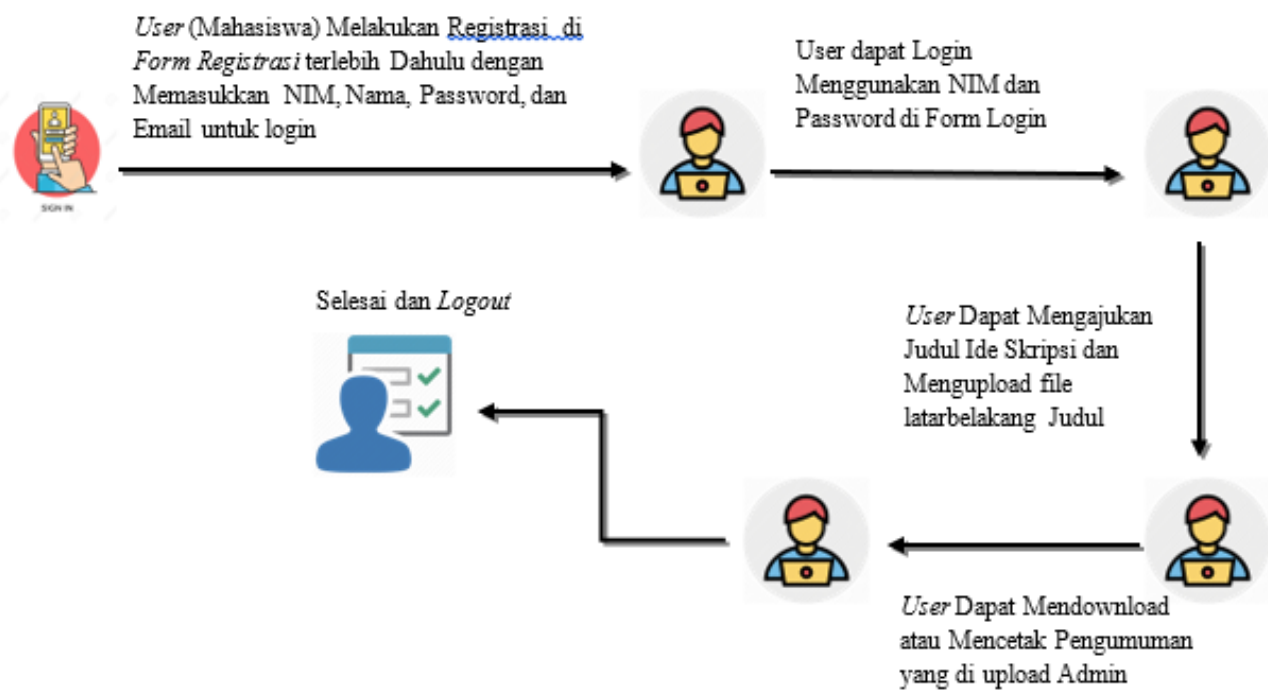

Figure 2. Student System Access Flow

Figure 3 is the system access flow for academic advisory lecturers. 


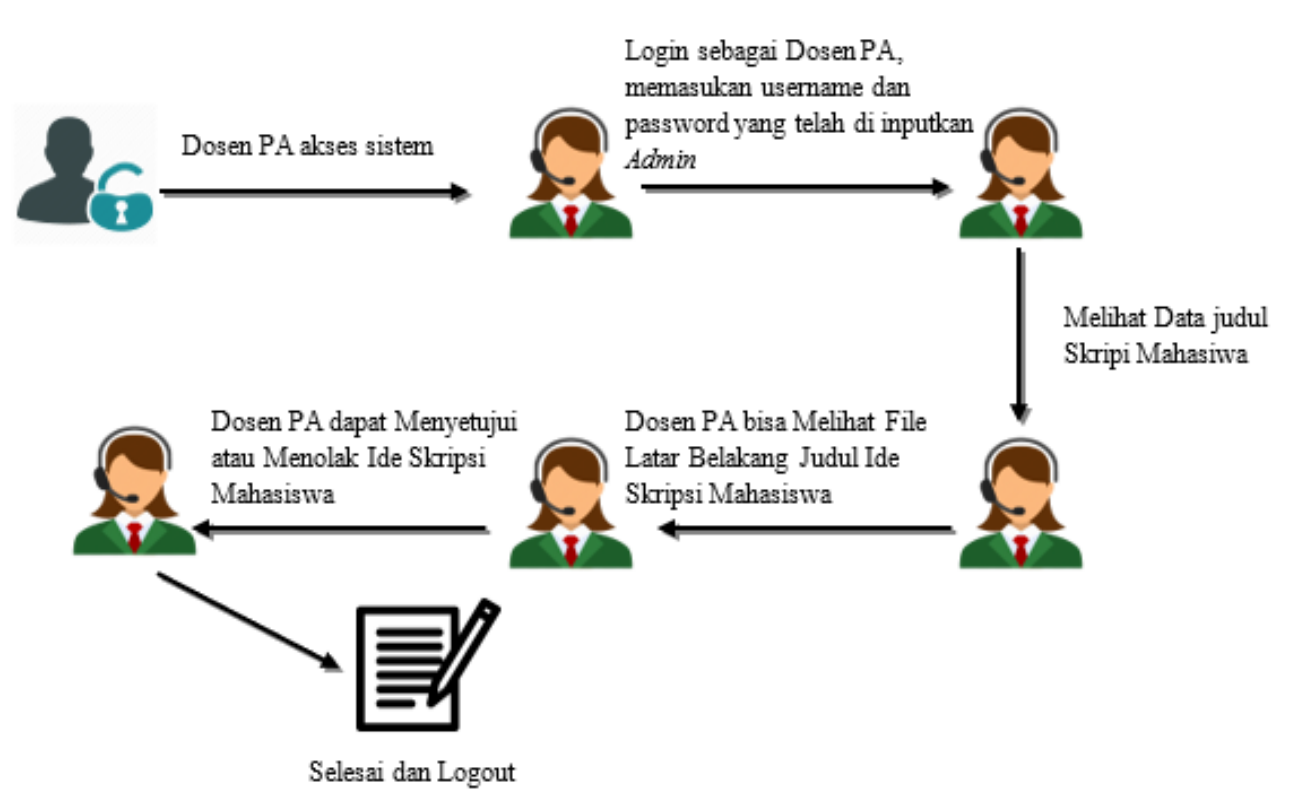

Figure 3. Access Flow of Academic Advisory Lecturer System

Figure 4 is a use case diagram of this system.

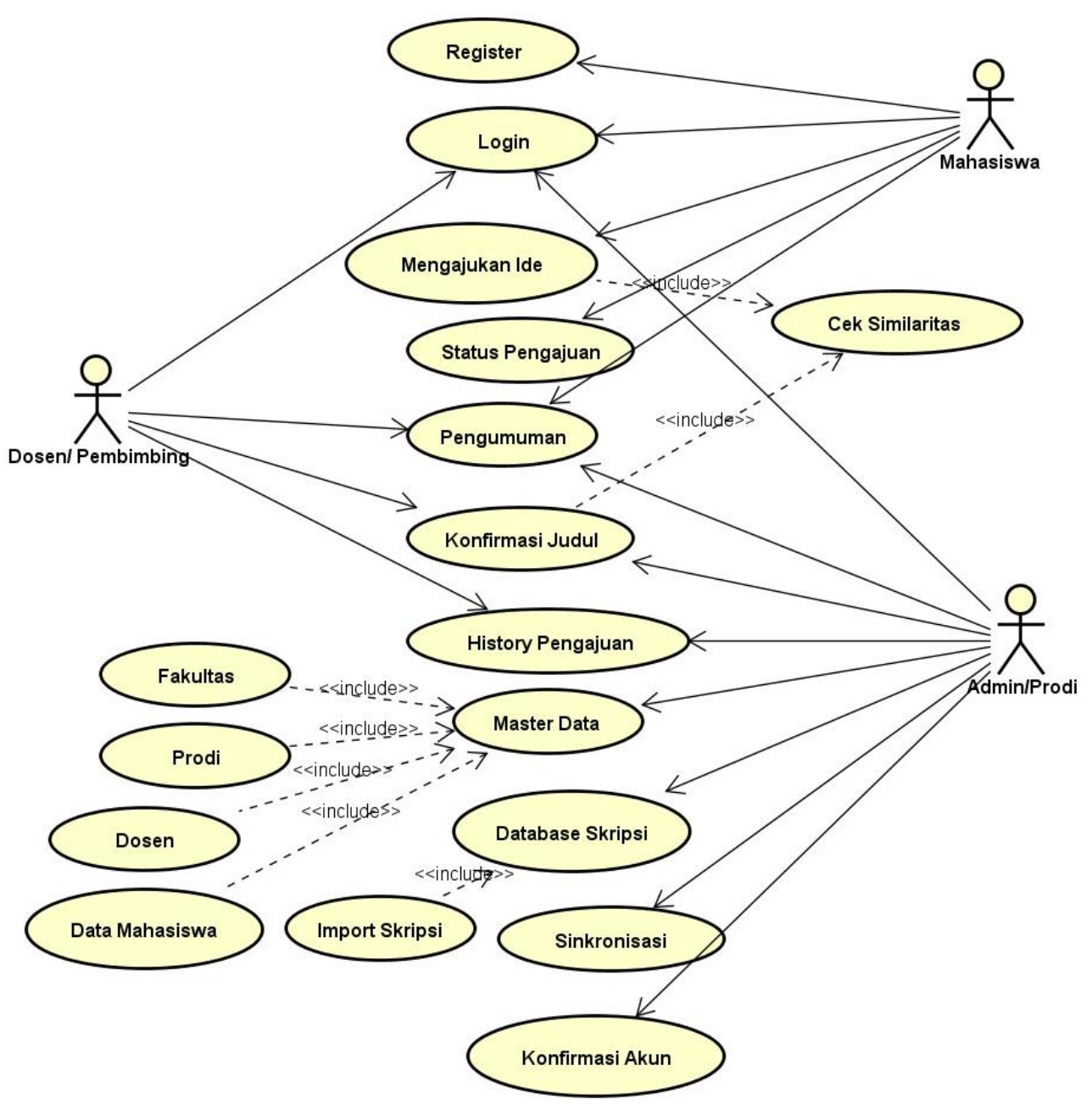


Figure 4. Use Case Diagram System

The main syntax/coding of this thesis title submission system is as follows.

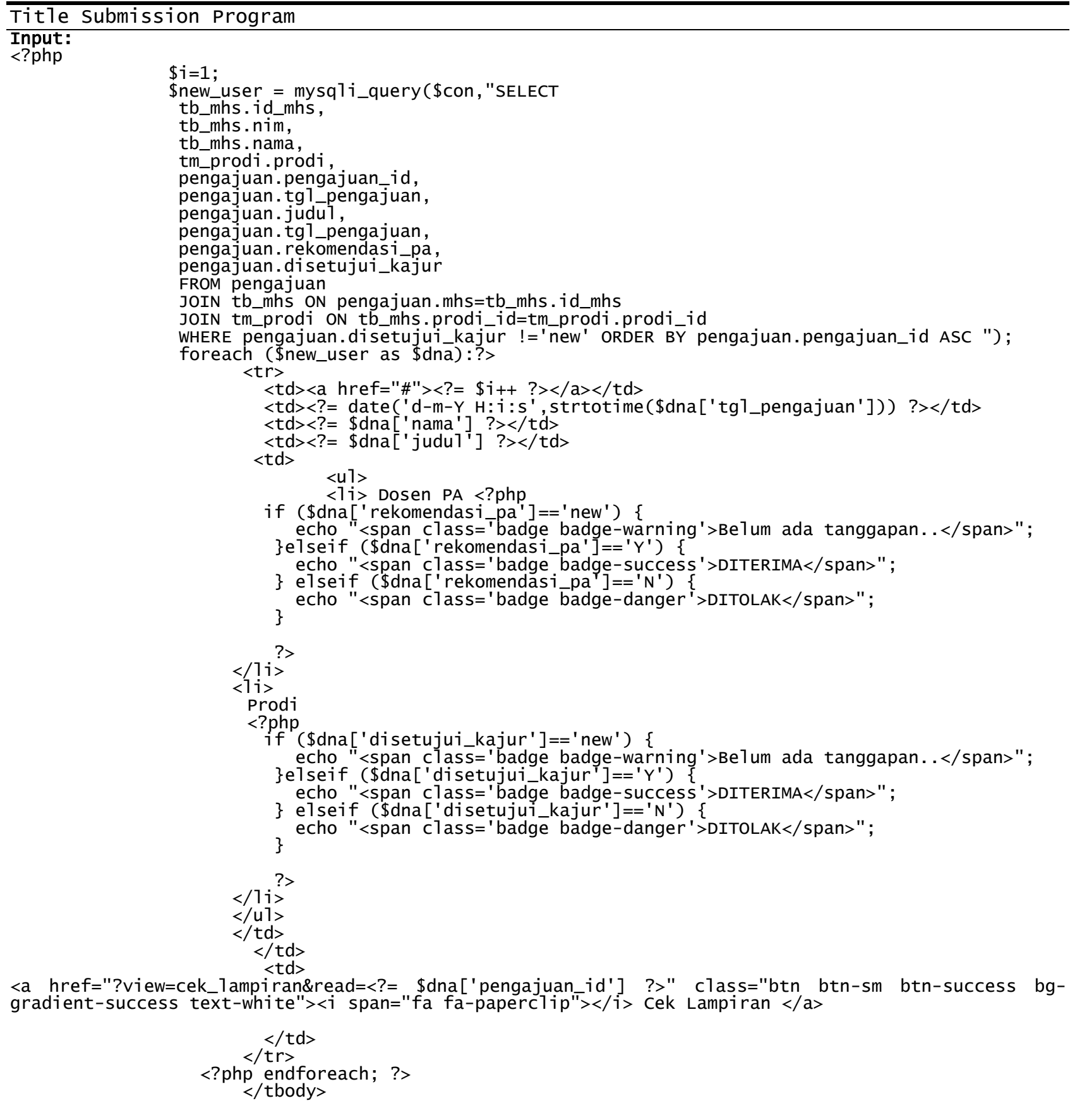

Based on the coding above, it produces a display like Figure 5. 


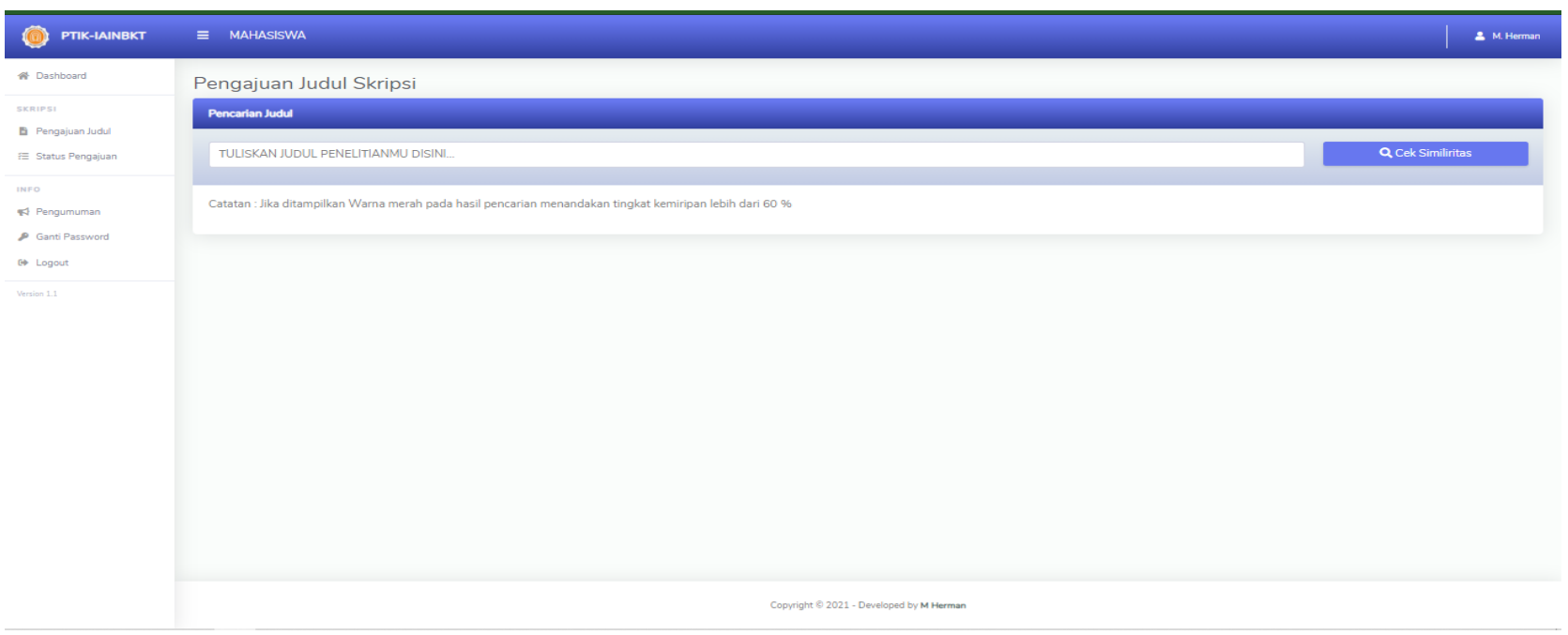

Figure 5. System View

The validity test results obtained a value of 0.87 with valid criteria. For practicality testing, the score is 1 with very practical criteria. Furthermore, the effectiveness test results get a value of 0.89 with very effective criteria.

\section{Conclusion}

Based on the results of the research that has been carried out and the description above, it can be concluded that with the presence of the design of the Thesis Title Submission System, the researchers have succeeded in creating a Web-Based Thesis Title Submission system using codeigniter 3 at the PTIK IAIN Bukittinggi Study Program. Generates a website with the URL https://abs.orbitiainbkt.com . In addition, this information system is very helpful for the Study Program, especially the Head of the Study Program and Students in the Administrative Process of Submitting a thesis so that the results will be more valid, practical, and effective.

\section{References}

[1] Ninla Elmawati Falabiba et al., "Pengertian Skripsi," Pap. Knowl. . Towar. a Media Hist. Doc., vol. 5, no. 2, pp. 40-51, 2014.

[2] Aditya Tjipta Kusuma, “Phenomenological Qualitative Study On Psychology Colleger Of Diponegoro University Semarang," vol. 1, no. 1, pp. 1-27, 2015.

[3] A. N. Khomarudin and L. Efriyanti, "Pengembangan Media Pembelajaran Mobile Learning Berbasis Android Pada Mata Kuliah Kecerdasan Buatan," J. Educ. J. Educ. Stud., vol. 3, no. 1, pp. 72-87, 2018, doi: 10.30983/educative.v3i1.543.

[4] R. R. Fadila, W. Aprison, and H. A. Musril, "Perancangan Perizinan Santri Menggunakan Bahasa Pemograman PHP / MySQL Di SMP Nurul Ikhlas," vol. 11, no. 2, pp. 94-105, 2019.

[5] L. R. Aiken, “Content Validity and Reliability Of Single Items or Questionnaires,” Educ. Psychol. Meas., vol. 40, no. 4, pp. 955-959, 1980, doi: 10.1177/001316448004000419.

[6] R. Sagita, F. Azra, and M. Azhar, "Pengembangan Modul Konsep Mol Berbasis Inkuiri Terstruktur Dengan Penekanan Pada Interkoneksi Tiga Level Representasi Kimia Untuk Kelas X SMA," J. Eksakta Pendidik., vol. 1, no. 2, pp. 25-32, 2017, doi: 10.24036/jep.v1i2.48.

[7] R. R. Hake, “Analyzing Change/Gain Scores,” Educ. Psychol. Meas., pp. 1-4, 1985. 